\title{
IGF-I treatment of insulin resistance
}

Anna McDonald, Rachel M Williams, Fiona M Regan, Robert K Semple ${ }^{1}$ and David B Dunger

University of Cambridge, Department of Paediatrics, Box 116, Addenbrookes Hospital, Hills Road, Cambridge, CB2 2QQ, UK and ${ }^{1}$ Department of Clinical Biochemistry, Box 232, Addenbrooks Hospital, Hills Road, Cambridge, CB2 2QQ, UK

(Correspondence should be addressed to D B Dunger; Email: dbd25@cam.ac.uk)

\begin{abstract}
Severe insulin resistance resulting from known or putative genetic defects affecting the insulin receptor or post-insulin receptor signalling represents a clinical spectrum ranging from Donohue's and Rabson-Mendenhall syndrome, where the genetic defect is identified, through to the milder phenotype of type A insulin resistance, where a genetic defect can only be detected in around $10 \%$ of cases. Paradoxically, subjects with these conditions may present with hypoglycaemia due to mismatch of post-prandial glucose excursion and compensatory hyperinsulinaemia. Ultimately, treatment with insulin and insulin sensitisers will be unsuccessful and subjects may succumb to diabetes or its complications. Recombinant human IGF-I alone or combined with its binding protein (IGFBP-3) provides an alternative therapy as IGF-I receptor shares structural and functional homology with the insulin receptor and recombinant human insulin-like growth factor I (rhIGF-I) therapy could improve glucose disposal by signalling through the IGF-I receptor, whilst reducing the adverse effects of high insulin concentrations. There are also data which indicate that IGF-I signalling through the IGF-I receptor on the pancreatic $\beta$-cell may be important in maintaining insulin secretion. Pilot studies confirmed that rhIGF-I could reduce glucose and insulin levels in subjects with type A insulin resistance and those with Rabson-Mendenhall syndrome with sustained beneficial effects on HbA1c. Continued study has confirmed efficacy of rhIGF-I when combined with IGFBP-3 in the treatment of Donohue's and type A insulin resistance subjects. Observations that IGF-I treatment can improve C-peptide levels in these subjects may indicate that it might be more valuable as a first line intervention to preserve $\beta$-cell function, rather than its current use as a medication of last resort in subjects where all other therapies have failed.
\end{abstract}

European Journal of Endocrinology 157 S51-S56

\section{Introduction}

Insulin resistance has been defined as a need for greater than normal amounts of insulin to elicit a quantitatively normal response (1). However, this definition does not reflect the possibility, which can exist in some rare conditions, that the insulin resistance may be selective and only relate to particular functions of insulin. The definition proposed by Kahn in 1976 is probably more appropriate as it states that insulin resistance exists whenever normal concentrations of insulin produce less than normal biological responses with respect to

1) Glucose uptake

2) Suppression of hepatic glucose production

3) Decreased lipolysis

4) Increased lipogenesis

5) Prevention of proteolysis.

This paper was presented at the Ipsen symposium, 'The evolving biology of growth and metabolism', Lisbon, Portugal, 16-18 March 2007. Ipsen has supported the publication of these proceedings.
Insulin resistance is a feature of normal pubertal development, where it largely relates to impairment of insulin-stimulated muscle glucose uptake (2). The resulting compensatory hyperinsulinaemia may inhibit proteolysis and contribute to anabolism during puberty (3). Similarly, the insulin resistance that develops during prolonged fasting or starvation may relate to growth hormone-induced lipolysis (4), reflecting the importance of survival advantage of changing from the use of glucose as the primary energy substrate to the mobilisation of fat for energy needs. The insulin resistance of starvation is mediated through counter-regulatory hormones such as growth hormone and cortisol, and pathological conditions leading to excess of either of these hormones will lead to insulin resistance (5).

Insulin resistance is also a feature of obesity in the normal population, where it has been linked to the increased deposition of visceral fat and increased rates of lipolysis $(6,7)$. Increased release of non-esterified fatty acids, particularly from the visceral fat depot, can lead to intramyocellular and intrahepatic fat deposition 
$(8,9)$. It is the build up of that ectopic lipid or, perhaps more particularly, the failure to effectively metabolise the lipid that leads to insulin resistance (10). Visceral fat is also a source of a wide range of peptides, which can affect insulin sensitivity and lead to generalised inflammation, which may also be part of the pathogenesis of insulin resistance of obesity (see Weiss chapter; this issue S39-S45).

Such ectopic deposition of fat is an important cause of insulin resistance in syndromes of lipodystrophy (11). There are multiple forms of lipodystrophy and most are very rare. Kobberling/Dunnigan syndrome (due to a lamin gene defect) is characterised by partial lipoatrophy involving the trunk and the limbs but often sparing the face (12). Patients with this condition, which generally develops around the time of puberty, are unable to deposit fat in the abnormal adipocytes and this leads to severe hepatic fat deposition and insulin resistance. Recently, treatment with recombinant human leptin has proved efficacious in leptin-deficient lipodystrophy by reducing fat intake and perhaps through direct effects on insulin sensitivity (13). Patients with partial lipodystrophy related to mutations of PPAR $-\gamma$ are also insulin resistant and develop a wide spectrum of abnormalities including hepatic steatosis, hypertension, diabetes and dyslipidaemia (14). PPAR- $\gamma$ is the cognate receptor for the thiazolidinediones, a class of drugs frequently used in the treatment of type 2 diabetes. These drugs have the ability to redistribute visceral fat to s.c. depots thus ameliorating effects on insulin sensitivity (15). Leptin and thiazolidinediones have been used to try and reverse the insulin resistance in other rare genetic disorders relating to the insulin receptor and impaired insulin action (49).

\section{Primary disorders of insulin action}

Severe insulin resistance, secondary to impaired insulin signalling, encompasses a wide range of rare disorders including genetic defects in the insulin receptor and more complex syndromes, associated for example with dwarfism and skeletal dysplasia where the genetic basis is unknown (see Table 1).

The most severe form of insulin resistance occurs in Donohue's syndrome (leprechaunism), where there are homozygous or compound heterozygous mutations in the regulatory or coding domains of the insulin receptor, resulting in what is effectively a functionally null receptor (16). These affected individuals present in the newborn period with severe intrauterine growth retardation, dysmorphic features such as thick lips, upturned nostrils, prominent eyes and low set posteriorly rotated ears. They are born with very little s.c. fat, distended abdomen, enlarged genitalia in the males and cystic ovaries in the females (17). As they effectively have a null mutation of the insulin receptor, insulin levels may exceed $10000 \mathrm{pmol} / \mathrm{l}$ yet, unlike animal
Table 1 Classification of severe insulin resistance.

\begin{tabular}{ll}
\hline Aetiology & \multicolumn{1}{c}{ Clinical syndrome } \\
\hline $\begin{array}{c}\text { Mutations of the } \\
\text { insulin receptor }\end{array}$ & $\begin{array}{l}\text { Donohue's syndrome (leprechaunism) } \\
\text { Rabson-Mendenhall syndrome } \\
\text { Type A insulin resistance } \\
\text { Lipodystrophic disorders (partial or } \\
\text { generalised; inherited or acquired) } \\
\text { Type C insulin resistance (HAIR-AN } \\
\text { in insulin action } \\
\text { syndrome; PCOS) }\end{array}$ \\
$\begin{array}{c}\text { Type B insulin resistance } \\
\text { antibodies }\end{array}$ & $\begin{array}{c}\text { Associated with skeletal dysplasia, } \\
\text { Others }\end{array}$ \\
Alstrom syndrome, myotonic dystrophy
\end{tabular}

models with similar genetic defects, these babies do not develop diabetic ketoacidosis (18). Indeed, initially the major clinical problem may be hypoglycaemia followed by post-prandial hyperglycaemia. They may require continuous nasogastric glucose infusions, and treatment with insulin or insulin sensitisers rarely reverses the decline towards diabetes. The majority of babies with Donohue's syndrome will die within the first 2 years of life.

Rabson-Mendenhall syndrome is also the result of mutations of the insulin receptor but the features may be much milder, with presentation during childhood with poor growth, insulin resistance, acanthosis nigricans, hirsutism, abnormal nails and dentition, phallic enlargement and occasional pineal hyperplasia (19-21). These patients will eventually develop severe insulin-resistant diabetes requiring very large doses of insulin to achieve normoglycaemia. Death is inevitable from intractable diabetic ketoacidosis or the complications of diabetes.

Type A insulin resistance is at the least severe end of the spectrum and thought to arise from mutations at the insulin receptor or in post-receptor signalling. Severe insulin resistance might be suspected in an insulin-dependent subject requiring more than 200 units of insulin a day but, paradoxically, many of the patients with type A insulin resistance present with hypoglycaemia. They have elevated fasting insulin levels in excess of $150 \mathrm{pmol} / \mathrm{l}$ (normal range $<60 \mathrm{pmol} / \mathrm{l}$ ), which may be sufficient to control fasting glucose levels but leads to a mismatch between glucose and insulin post-prandially and thus hypoglycaemia. Type A insulin resistance was originally used to describe lean adolescent females with the phenotype of hyperinsulinism, glucose intolerance or frank diabetes mellitus, acanthosis nigricans, virilisation and polycystic ovary syndrome (22). However, the diagnosis now encompasses both males and females in teenage or early adult years, who are not obese but have severe insulin resistance and acanthosis nigricans in the absence of insulin receptor autoantibodies (19). Despite the common presenting features, this is undoubtedly a heterogeneous group of patients and at present only about $10 \%$ have detectable genetic defects in the insulin 
receptor (22-24). It is likely that some will have defects in post-insulin receptor signalling (50). These patients are not predisposed to the significantly early mortality seen in the other two groups, but are likely to be at high risk of long-term complications secondary to their hyperglycaemia.

The treatment of any condition resulting in severe insulin resistance is challenging and often unsuccessful. Initially, treatment may consist of the use of insulinsensitising drugs such as metformin or thiazolidinediones. Eventually, patients end up on escalating doses of insulin with progressive decline in $\beta$-cell function, resulting in considerable morbidity and mortality from diabetes and its complications.

\section{Treatment with recombinant human insulin-like growth factor I (rhIGF-I) in severe insulin resistance}

Insulin, proinsulin, IGF-I and IGF-II show remarkable structural and in part sequence homology $(25,26)$. Similarly, the insulin and the type 1 IGF receptor are structurally related and share common post-receptor signalling pathways (27). In vitro and in vivo both insulin and IGF-I are capable of stimulating glucose uptake, glycogen synthesis and the inhibition of protein catabolism $(28,29)$. IGF-I has little effect on the adipocyte because there are no IGF-I receptors on that tissue (30). The mature liver also lacks IGF-I receptors but, nevertheless, rhIGF-I has been shown to suppress hepatic glucose production through unknown mechanisms $(31,32)$. It was therefore anticipated that rhIGF-I therapy in patients with severe insulin resistance might be efficacious.

The aim of IGF-I therapy in severe insulin resistance would be primarily to stimulate peripheral glucose utilisation and suppress hepatic glucose production, thereby reducing the drive for compensatory hyperinsulinaemia; the high insulin levels acting through the IGF-I receptor being responsible for many of the pathological features including acanthosis nigricans and polycystic ovaries $(33,34)$. The long-term aim of therapy would be to improve glycaemia, and in the case of Donohue's syndrome, promote linear growth and prolong longevity.

The first reports of the use of recombinant IGF-I therapy in severe insulin resistance were in the early 1990s and largely involved the treatment of patients with type A syndrome. The results of these studies are summarised in Table 2. In 1991, Schoenle et al. were the first to demonstrate that a bolus injection of recombinant IGF-I could reduce both insulin and blood glucose levels in patients with severe insulin resistance (35). Subsequently, other groups showed that IGF-I therapy in patients with severe type A insulin resistance could consistently reduce glucose and insulin levels. Kuzuyu et al. undertook the longest of these studies, reporting up to 16 months treatment with rhIGF-I in 11 patients, who showed lowering of fasting and post-prandial glucose plus decreases in fructosamine and \%HbA1c (36). In all of these early studies, very high doses of rhIGF-I were used and complications

Table 2 Summary design and outcome of studies on recombinant human insulin-like growth factor I (rhIGF-I) treatment in syndromes of severe insulin resistance.

\begin{tabular}{|c|c|c|}
\hline Authors & Trial design & Outcome \\
\hline Schoenle et al. (35) & Three subjects twice received i.v. doses with rhIGF-I & $\begin{array}{l}\text { Immediate slow fall in blood glucose, parallel fall in } \\
\text { insulin and C-peptide levels }\end{array}$ \\
\hline Morrow et al. (45) & $\begin{array}{l}\text { Two subjects received } 3-4 \text { weeks treatment with rhIGF- } \\
\text { I. Pre- and post-treatment assessment with } 24 \mathrm{~h} \\
\text { glucose and insulin profile, standardised liquid meal, } \\
\text { insulin tolerance test, insulin suppression test and i.v. } \\
\text { glucose tolerance test }\end{array}$ & $\begin{array}{l}\text { Decreased endogenous insulin levels, normalisation of } \\
\text { response to i.v. insulin, reduced steady-state plasma } \\
\text { glucose }\end{array}$ \\
\hline Zenobi et al. (46) & $\begin{array}{l}\text { Two subjects received } 10 \text { days treatment with rhIGF-I. } \\
\text { Fasting and post-prandial glucose, insulin, C-peptide } \\
\text { and proinsulin levels measured pre- and post- } \\
\text { treatment }\end{array}$ & $\begin{array}{l}\text { Fasting glucose levels decreased and fasting insulin, } \\
\text { C-peptide, and proinsulin levels decreased by } \sim 65 \% \\
\text { during treatment }\end{array}$ \\
\hline Kuzuya et al. (36) & $\begin{array}{l}11 \text { subjects received up to } 16 \text { months treatment with } \\
\text { rhIGF-I. Fasting and post-prandial glucose, fructosa- } \\
\text { mine and \%HbA1C were measured pre- and } \\
\text { throughout treatment }\end{array}$ & $\begin{array}{l}\text { Lowering of fasting and post-prandial glucose and } \\
\text { decreases in fructosamine and \%HbA1C }\end{array}$ \\
\hline Moses et al. (47) & $\begin{array}{l}\text { Six subjects (four out of six subjects had overt diabetes, } \\
\text { two with normal glucose tolerance) received } 1 \text { months } \\
\text { treatment with rhIGF-I. Baseline investigation to } \\
\text { quantify carbohydrate tolerance, insulin secretion and } \\
\text { insulin action }\end{array}$ & $\begin{array}{l}\text { Three out of four diabetic subjects showed normalisation } \\
\text { of fasting and post-prandial glucose levels. Remaining } \\
\text { two subjects dramatically decreased insulin and } \\
\text { triglyceride levels }\end{array}$ \\
\hline Vestergaard et al. (48) & $\begin{array}{l}\text { Four subjects received high-dose treatment with rhIGF-I } \\
\text { for } 2 \text { weeks, three subjects received low dose for } 10 \\
\text { weeks. Pre- and post-treatment fasting glucose, } \\
\text { insulin, C-peptide and proinsulin plus \%HbA1C and } \\
\text { fructosamine were measured }\end{array}$ & $\begin{array}{l}\text { High-dose treatment lowered fasting glucose and insulin } \\
\text { levels, whereas metabolic and glycaemic effects of } 10 \\
\text { weeks low-dose treatment were modest }\end{array}$ \\
\hline
\end{tabular}


Table 3 Effects of recombinant human insulin-like growth factor I (rhIGF-I)/IGF binding protein-3 (IGFBP-3) complex in a female subject with type $A$ insulin resistance. Therapy was started at $0.5 \mathrm{mg} / \mathrm{kg}$ per day and increased up to a total daily dose of $2 \mathrm{mg} / \mathrm{kg}$ per day over a 16-week period.

\begin{tabular}{lll}
\hline & \multicolumn{1}{c}{ Pre-treatment } & Post-treatment \\
\hline \%HbA1c & 8.1 & 5.0 \\
Intramyocellular lipid & 8.6 & 7.8 \\
Intrahepatic fat & $9.4 \pm 0.7 \%$ & $5.9 \pm 1.2 \%$ \\
\hline
\end{tabular}

Intramyocellular lipid was quantified using magnetic resonance spectroscopy and hepatic fat using magnetic resonance imaging.

were observed relating to muscle pain, fluid retention, benign intercranial hypertension and worsening retinopathy.

The full therapeutic potential of rhIGF-I therapy in severe insulin resistance has not been explored, because until very recently recombinant peptides were not available for study. A study using rhIGF-I/IGF binding protein-3 (IGFBP-3) in a patient with Donohue's syndrome reported normalisation of glucose with prevention of postnatal growth failure (37). Recently, we and others have been able to explore the efficacy of IGF-I combined with its principle binding protein IGFBP-3 in a variety of diabetic conditions $(38,39)$. Combining IGF-I with its principle binding protein prolongs its half life and results in decreased concentrations of free IGF-I and improved tolerability $(38,40)$. We have preliminary unpublished data from phase 2 clinical trials in subjects with type A insulin-resistant syndrome indicating that treatment with rhIGF-I/ IGFBP-3 complex may improve glycaemic control and lead to reductions in $\mathrm{HbAlc}$. Insulin sensitivity improves and there were measurable reductions in intrahepatic and intramyocellular lipid during a 4-month treatment period (Table 3, Figs 1 and 2).

An important observation from these new studies is that IGF-I/IGFBP-3 complex therapy appears to improve $\beta$-cell function and improve glucose-stimulated C-peptide responses. This may be the result of reduced glucotoxicity, but recent animal data indicate that IGF-I
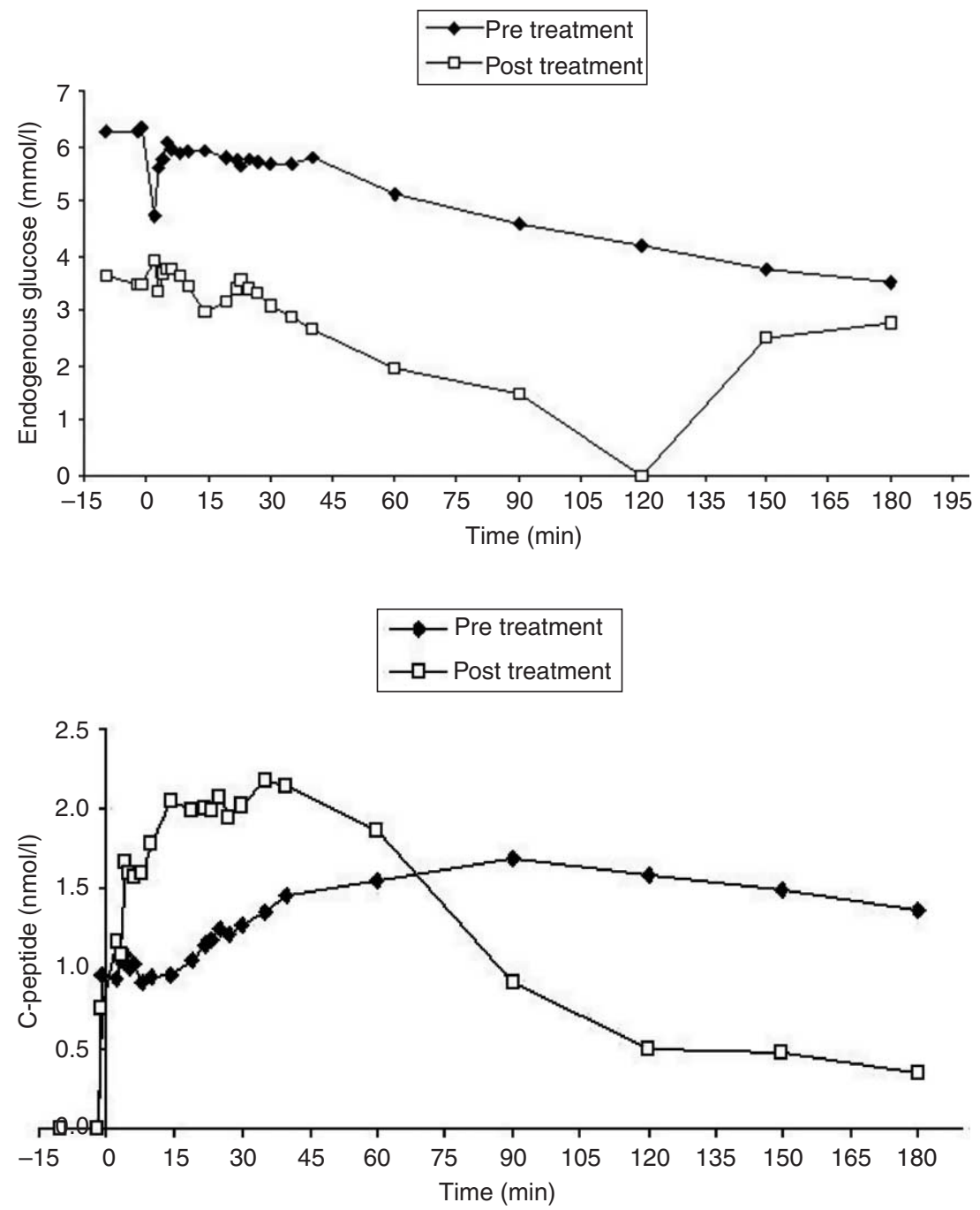

Figure 1 Endogenous hepatic glucose production during i.v. glucose tolerance test before and after treatment with IGF-I/IGFBP-3 in a patient with type $A$ insulin resistance.
Figure $2 \mathrm{C}$-peptide response during i.v. glucose tolerance test in a subject with type $A$ insulin resistance before and after treatment with rhIGFI/IGFBP-3 complex. 
signalling through the IGF-I receptor on the $\beta$-cell may have an important role in maintaining $\beta$-cell mass and insulin secretion (41-44). This might indicate that early rather than later treatment with recombinant IGF-I may be beneficial and there are two remarkable reports of children with Donohue's syndrome, treated with IGFI from a very early age, who have shown sustained improvements in insulin sensitivity and growth over several years.

\section{Conclusions}

Syndromes of severe insulin resistance are extremely rare and encompass a very wide range of heterogeneous conditions. In some, with severe lipoatrophy, leptin therapy may bring partial benefit but the long-term outcome of such treatment is unknown. In other patients, the use of insulin sensitisers may delay the development of diabetes but inevitably most patients will ultimately require insulin therapy, with escalating doses as $\beta$-cell function declines. Treatment with recombinant IGF-I or IGF-I/IGFBP-3 is based on sound physiological principles and appears to be efficacious, at least in the short term. Longer term studies are needed to determine the risk-benefit ratio of such interventions, the ideal doses that should be used and the age at which treatment should be initiated.

\section{Disclosure}

This paper forms part of a European Journal of Endocrinology supplement, supported by Ipsen. The authors disclose: RM Williams, FM Regan, RK Semple and A McDonald have no potential conflicting relationships with Ipsen. DB Dunger is a member of the Endocrine Scientific Advisory Board for Ipsen. This article was subject to rigorous peer review before acceptance and publication.

\section{References}

1 Yalow RS \& Berson SA. Immunoassay of endogenous plasma insulin in man. Journal of Clinical Investigation 196039 $1157-1175$.

2 Caprio S, Cline G, Boulware S, Permanente C, Shulman GI, Sherwin RS \& Tamborlane WV. Effects of puberty and diabetes on metabolism of insulin-sensitive fuels. American Journal of Physiology 1994266 E885-E891.

3 Arslanian SA \& Kalhan SC. Protein turnover during puberty in normal children. American Journal of Physiology $1996 \mathbf{2 7 0}$ E79-E84.

4 Moller N, Porksen N, Ovesen P \& Alberti KG. Evidence for increased sensitivity of fuel mobilization to growth hormone during shortterm fasting in humans. Hormone and Metabolic Research 199325 $175-179$.
5 Kahn CR, Goldfine ID, Neville DM, Jr \& De Meyts P. Alterations in insulin binding induced by changes in vivo in the levels of glucocorticoids and growth hormone. Endocrinology 1978103 1054-1066.

6 Bergman RN \& Ader M. Free fatty acids and pathogenesis of type 2 diabetes mellitus. Trends in Endocrinology and Metabolism 200011 351-356.

7 Ostman J, Arner P, Engfeldt P \& Kager L. Regional differences in the control of lipolysis in human adipose tissue. Metabolism 197928 1198-1205.

8 Oakes ND, Cooney GJ, Camilleri S, Chisholm DJ \& Kraegen EW. Mechanisms of liver and muscle insulin resistance induced by chronic high-fat feeding. Diabetes 199746 1768-1774.

9 Petersen KF \& Shulman GI. Etiology of insulin resistance. American Journal of Medicine 2006119 S10-S16.

10 Shulman GI. Cellular mechanisms of insulin resistance. Journal of Clinical Investigation 2000106 171-176.

11 Garg A, Peshock RM \& Fleckenstein JL. Adipose tissue distribution pattern in patients with familial partial lipodystrophy (Dunnigan variety). Journal of Clinical Endocrinology and Metabolism $1999 \mathbf{8 4}$ 170-174.

12 Garg A, Vinaitheerthan M, Weatherall PT \& Bowcock AM. Phenotypic heterogeneity in patients with familial partial lipodystrophy (Dunnigan variety) related to the site of missense mutations in lamin a/c gene. Journal of Clinical Endocrinology and Metabolism 200186 59-65.

13 Javor ED, Cochran EK, Musso C, Young JR, Depaoli AM \& Gorden P. Long-term efficacy of leptin replacement in patients with generalized lipodystrophy. Diabetes 200554 1994-2002.

14 Semple RK, Chatterjee VK \& O'Rahilly S. PPAR gamma and human metabolic disease. Journal of Clinical Investigation 2006 $116581-589$.

15 Miyazaki Y, Matsuda M \& DeFronzo RA. Dose-response effect of pioglitazone on insulin sensitivity and insulin secretion in type 2 diabetes. Diabetes Care 200225 517-523.

16 Taylor SI. Lilly lecture: molecular mechanisms of insulin resistance. Lessons from patients with mutations in the insulinreceptor gene. Diabetes 199241 1473-1490.

17 Donohue WL \& Uchida I. Leprechaunism: a euphemism for a rare familial disorder. Journal of Pediatrics 195445 505-519.

18 Ogilvy-Stuart AL, Soos MA, Hands SJ, Anthony MY, Dunger DB \& O'Rahilly S. Hypoglycemia and resistance to ketoacidosis in a subject without functional insulin receptors. Journal of Clinical Endocrinology and Metabolism 200186 3319-3326.

19 Mantzoros CS \& Flier JS. Insulin resistance: the clinical spectrum. Advances in Endocrinology and Metabolism 19956 193-232.

20 Rabson SM \& Mendenhall EN. Familial hypertrophy of pineal body, hyperplasia of adrenal cortex and diabetes mellitus; report of 3 cases. American Journal of Clinical Pathology 195626 283-290.

21 West RJ, Lloyd JK \& Turner WM. Familial insulin-resistant diabetes, multiple somatic anomalies, and pineal hyperplasia. Archives of Disease in Childhood $1975 \mathbf{5 0} 703-708$.

22 Kahn CR, Flier JS, Bar RS, Archer JA, Gorden P, Martin MM \& Roth J. The syndromes of insulin resistance and acanthosis nigricans. Insulin-receptor disorders in man. New England Journal of Medicine 1976294 739-745.

23 Moller DE, Cohen O, Yamaguchi Y, Assiz R, Grigorescu F, Eberle A, Morrow LA, Moses AC \& Flier JS. Prevalence of mutations in the insulin receptor gene in subjects with features of the type A syndrome of insulin resistance. Diabetes 199443 247-255.

24 O'Rahilly S \& Moller DE. Mutant insulin receptors in syndromes of insulin resistance. Clinical Endocrinology 199236 121-132.

25 Zapf J, Schoenle E \& Froesch ER. Insulin-like growth factors I and II: some biological actions and receptor binding characteristics of two purified constituents of nonsuppressible insulin-like activity of human serum. European Journal of Biochemistry 197887 285-296.

26 Rinderknecht E \& Humbel RE. The amino acid sequence of human insulin-like growth factor I and its structural homology with proinsulin. Journal of Biological Chemistry $19782532769-2776$. 
27 Ullrich AGA. Insulin-like growth factor I receptor primary structure: comparison with insulin receptor suggests structural determinants that define functional specifity. EMBO Journal $198652503-2512$.

28 Dimitriadis G, Parry-Billings M, Bevan S, Dunger D, Piva T, Krause U, Wegener G \& Newsholme EA. Effects of insulin-like growth factor $I$ on the rates of glucose transport and utilization in rat skeletal muscle in vitro. Biochemical Journal $1992285269-274$.

29 Di Cola G, Cool MH \& Accili D. Hypoglycemic effect of insulin-like growth factor-1 in mice lacking insulin receptors. Journal of Clinical Investigation $1997992538-2544$.

30 Caro JF, Poulos J, Ittoop O, Pories WJ, Flickinger EG \& Sinha MK. Insulin-like growth factor I binding in hepatocytes from human liver, human hepatoma, and normal, regenerating, and fetal rat liver. Journal of Clinical Investigation $1988 \mathbf{8 1}$ 976-981.

31 Acerini CL, Harris DA, Matyka KA, Watts AP, Umpleby AM, Russell-Jones DL \& Dunger DB. Effects of low-dose recombinant human insulin-like growth factor-I on insulin sensitivity, growth hormone and glucagon levels in young adults with insulindependent diabetes mellitus. Metabolism 1998 47 1481-1489.

32 Simpson HL, Jackson NC, Shojaee-Moradie F, Jones RH, RussellJones DL, Sonksen PH, Dunger DB \& Umpleby AM. Insulin-like growth factor I has a direct effect on glucose and protein metabolism, but no effect on lipid metabolism in type 1 diabetes. Journal of Clinical Endocrinology and Metabolism 200489 425-432.

33 Musso C, Cochran E, Moran SA, Skarulis MC, Oral EA, Taylor S \& Gorden P. Clinical course of genetic diseases of the insulin receptor (type A and Rabson-Mendenhall syndromes): a 30-year prospective. Medicine 200483 209-222.

34 Musso C, Shawker T, Cochran E, Javor ED, Young J \& Gorden P. Clinical evidence that hyperinsulinaemia independent of gonadotropins stimulates ovarian growth. Clinical Endocrinology 200563 $73-78$.

35 Schoenle EJ, Zenobi PD, Torresani T, Werder EA, Zachmann M \& Froesch ER. Recombinant human insulin-like growth factor I (rhIGF I) reduces hyperglycaemia in patients with extreme insulin resistance. Diabetologia $199134675-679$.

36 Kuzuya H, Matsuura N, Sakamoto M, Makino H, Sakamoto Y, Kadswaki T, Suzuki Y, Kobayashi M, Akazawa Y, Nomura M, Yoshimasa Y, Kasuga M, Goji K, Nagakali S, Oyasu H \& Imura H. Trial of insulinlike growth factor I therapy for patients with extreme insulin resistance syndromes. Diabetes $1993 \mathbf{4 2} 696-705$.

37 Nakae J, Kato M, Murashita M, Shinohara N, Tajima T \& Fujieda K. Long-term effect of recombinant human insulin-like growth factor I on metabolic and growth control in a patient with leprechaunism. Journal of Clinical Endocrinology and Metabolism $199883542-549$.

38 Clemmons DR, Moses AC, McKay MJ, Sommer A, Rosen DM \& Ruckle J. The combination of insulin-like growth factor I and insulin-like growth factor-binding protein-3 reduces insulin requirements in insulin-dependent type 1 diabetes: evidence for in vivo biological activity. Journal of Clinical Endocrinology and Metabolism 200085 1518-1524.

39 Saukkonen T, Amin R, Williams RM, Fox C, Yuen KC, White MA, Umpleby AM, Acerini CL \& Dunger DB. Dose-dependent effects of recombinant human insulin-like growth factor (IGF)-I/IGF binding protein-3 complex on overnight growth hormone secretion and insulin sensitivity in type 1 diabetes. Journal of Clinical Endocrinology and Metabolism $2004894634-4641$.
40 Boonen S, Rosen C, Bouillon R, Sommer A, McKay M, Rosen D, Adams S, Broos P, Lenaerts J, Raus J, Vanderschueren D \& Geusens P. Musculoskeletal effects of the recombinant human IGFI/IGF binding protein-3 complex in osteoporotic patients with proximal femoral fracture: a double-blind, placebo-controlled pilot study. Journal of Clinical Endocrinology and Metabolism $2002 \mathbf{8 7}$ 1593-1599.

41 Bergerot I, Fabien N, Maguer V \& Thivolet C. Insulin-like growth factor-1 (IGF-1) protects NOD mice from insulitis and diabetes. Clinical and Experimental Immunology 1995102 335-340.

42 Hill DJ, Petrik J, Arany E, McDonald TJ \& Delovitch TL. Insulin-like growth factors prevent cytokine-mediated cell death in isolated islets of Langerhans from pre-diabetic non-obese diabetic mice. Journal of Endocrinology 1999161 153-165.

43 Chen W, Salojin KV, Mi QS, Grattan M, Meagher TC, Zucker P \& Delovitch TL. Insulin-like growth factor (IGF)-I/IGF-binding protein-3 complex: therapeutic efficacy and mechanism of protection against type 1 diabetes. Endocrinology $2004 \mathbf{1 4 5}$ 627-638.

44 Ueki K, Okada T, Hu J, Liew CW, Assmann A, Dahlgren GM, Peters JL, Shackman JG, Zhang M, Artner I, Satin LS, Stein R, Holzenberger M, Kennedy RT, Kahn CR \& Kulkarni RN. Total insulin and IGF-I resistance in pancreatic $\beta$ cells causes overt diabetes. Nature Genetics 200638 583-588.

45 Morrow LA, O'Brien MB, Moller DE, Flier JS \& Moses AC. Recombinant human insulin-like growth factor-I therapy improves glycemic control and insulin action in the type A syndrome of severe insulin resistance. Journal of Clinical Endocrinology and Metabolism 199479 205-210.

46 Zenobi PD, Glatz Y, Keller A, Graf S, Jaeggi-Groisman SE, Riesen WF, Schoenle EJ \& Froesch ER. Beneficial metabolic effects of insulin-like growth factor I in patients with severe insulinresistant diabetes type A. European Journal of Endocrinology 1994 $131251-257$

47 Moses AC, Morrow LA, O’Brien M, Moller DE \& Flier JS. Insulin-like growth factor I (rhIGF-I) as a therapeutic agent for hyperinsulinemic insulin-resistant diabetes mellitus. Diabetes Research and Clinical Practice 199528 S185-S194.

48 Vestergaard H, Rossen M, Urhammer SA, Muller J \& Pedersen O. Short- and long-term metabolic effects of recombinant human IGF-I treatment in patients with severe insulin resistance and diabetes mellitus. European Journal of Endocrinology 1997136 475-482.

49 Cochran E, Young JR, Sebring N, DePauoli A, Oral EA \& Gorden P. Efficacy of recombinant methionyl human leptin therapy for the extreme insulin resistance of the Rabson-Mendenhall syndrome. Journal of Clinical Endocrinology and Metabolism 2004 89 1548-1554.

50 George S, Rochford JJ, Wolfrum C, Gray SL, Schinner S, Wilson JC, Soos MA, Murgatroyd PR, Williams RM, Acerini CL, Duner DB, Barford D, Umpleby MA, Wareham NJ, Davies HA, Schafer AJ, Stoffel M, O'Rahilly S \& Barroso I. A family with severe insulin resistance and diabetes due to a mutation in AKT2. Science 2004 304 1325-1328.

Received 23 April 2007

Accepted 3 May 2007 